\title{
Penerapan Metode Profile Matching Untuk Menentukan Peserta Lomba Pramuka
}

\author{
Fauzan Yusak Ibrahim $^{1^{*}}$, Alam Supriyatna ${ }^{2}$ \\ Sistem Informasi \\ STIKOM Binaniaga \\ Email: alam@stikombinaniaga.ac.id
}

\begin{abstract}
The developmen. of the era requires humans to master science. Especially to achieve achievements as students, especially to continue to the next level / path of achievement, To get an achievement is not easy, one of them in the field of scouting competition, it takes effort and rigorous training, as well as rigorous selection to become SMK Negeri 1 Kota contest participants Bogor. Therefore we need a system that can take into account all the criteria that support the decision making of prospective participants. Decision making using the Profile Matching Method is the right thing to select students if it is suitable for competitions in certain fields. The decision results from the profile matching system based on the final value of the study, states that if the probability value of YES is greater than the probability of $N O$, the system works well, on the contrary if the probability value is NOT higher than the probability of YES, the system does not work properly. From the results of the research for the performance of the profile matching system in the category "Eligible". The percentage value of the test results on the system for each factor, namely: functionality of 69\%, efficiency of 70\%, and usability of 65\%. The total percentage of system quality is $90 \%$ (Eligible).
\end{abstract}

Keywords: Profile Matching;Eligible;Performance.

\begin{abstract}
ABSTRAK
Perkembangan zaman menuntut manusia untuk menguasai ilmu pengetahuan. Terutama untuk meraih prestasi sebagai pelajar, khususnya untuk melanjutkan ke jenjang selanjutnya /jalur prestasi, Untuk mendapatkan sebuah prestasi sangatlah tidak mudah, salah satunya dibidang lomba kepramukaan, butuh usaha dan latihan yang keras, serta seleksi yang ketat untuk menjadi peserta lomba SMK Negeri 1 Kota Bogor. Maka dari itu diperlukan suatu sistem yang dapat memperhitungkan segala kriteria yang mendukung dalam pengambilan keputusan calon peserta lomba. Pengambilan keputusan dengan menggunakan Metode Profile Matching merupakan hal yang tepat untuk menseleksi siswa apakah cocok untuk lomba dibidang tertentu. Hasil keputusan dari sistem profile matching berdasarkan nilai akhir dari penelitian, menyatakan bahwa jika nilai probabilitas YA lebih besar dari probabilitas TIDAK, maka sistem bekerja dengan baik, sebaliknya jika nilai probabilitas TIDAK lebih tinggi dari probabilitas YA, maka sistem tidak bekerja dengan baik. Dari hasil penelitian untuk unjuk kerja sistem profile matching masuk dalam kategori "Layak". Nilai persentase hasil pengujian pada sistem untuk setiap faktor, yaitu: functionality sebesar $69 \%$, efficiency sebesar $70 \%$, dan usability sebesar 65\%. Persentase total dari kualitas sistem adalah 90\% (Layak).
\end{abstract}

Kata Kunci: Profile Matching, Kelayakan, performance

\section{PENDAHULUAN}

\section{Latar Belakang}


Persaingan di dunia pendidikan tidak akan pernah terhenti khususnya dalam bidang non-akademik yang diwadahi dengan ekstrakurikuler, salah satunya adalah Kepramukaan. Kepramukaan adalah pendidikan nonformal atau wadah/organisasi yang diwajibkan di Indonesia. Dengan adanya Peraturan Menteri Pendidikan dan Kebudayaan Nomor 63, Tahun 2014 tentang Pendidikan Kepramukaan sebagai Kegiatan Ekstrakurikuler Wajib pada Pendidikan Dasar dan Pendidikan Menengah, ditambah dengan Undang - undang No. 12 Tahun 2010 tentang Gerakan Pramuka yang menjadikan Kepramukaan satu - satunya wadah yang mempunyai dasar negara dan diharapkan dapat membantu membentuk karakter generasi penerus Bangsa Indonesia, dengan adanya Kepramukaan peserta didik tidak hanya bisa mencari prestasi dalam bidang akademik tetapi peserta didik juga bisa mencari prestasi di bidang non-akademik karena perkembangannya kepramukaan ini juga menjadi ajang untuk mencari prestasi di bidang non-akademik. Sehingga, banyak intansi-intansi pendidikan yang mengutamakan peserta didik yang mempunyai prestasi di keorganisasian, karena dunia pendidikan maupun dunia pekerjaan yang pasti tidak akan pernah berhenti mencari penerus yang mempunyai prestasi lebih. Terutama keorganisasian yang diwadahi dengan kepramukaan.

Penentuan peserta didik untuk mengikuti lomba dengan memperhatikan :

a. Kemampuan untuk bersaing

b. Kemampuan menguasai materi, menurut Silabus Pramuka Penegak didalam kemampuan menguasai materi terdiri dari; faktor keagamaan, faktor fisik, faktor pengetahuan, faktor keaktifan, dan factor kedisiplinan.

Banyaknya hal yang bisa peserta didik capai selain prestasi juga bisa mendapatkan manfaat dalam keseharian seperti kedisiplinan, ketelitian, dan ke mahiran dalam menjalani hidup sehari-hari yang diajarkan dalam kepramukaan, dalam belajar kepramukaan dari anak-anak SD hingga ke Mahasiswa membuat mereka mendapatkan pengalaman yang lebih dari anak-anak yang tidak ikut organisasi. Kini persaingan dalam lomba di kepramukaan sangat banyak diminati oleh banyak peserta didik yang berlomba-lomba untuk menjadi juara dan mencari prestasi maupun pengalaman, karna beberapa perlombaan bisa membantu dalam meneruskan ke jenjang berikutnya tanpa tes reguler ataupun menambah nilai dalam menentukan masuk atau tidaknya ke sekolah yang diinginkan.

Banyak faktor yang mempengaruhi kesiapan suatu individu dalam menghadapi persaingan dengan di dunia pendidikan maupun di dunia pekerjaan. Salah satu faktor yang menentukan adalah mengikuti perlombaan. Keikutsertaan dalam lomba ini berarti melatih mental maupun mengevaluasi sejauh mana kemampuan peserta didik mampu bersaing. Pemilihan peserta didik dalam mengikuti perlombaan ini juga menentukan sejauh mana kesiapan peserta didik dalam membela nama baik sekolahnya masing - masing. Penentuan peserta didik yang tepat akan meminimumkan dalam persaingan juara dan mendapatkan prestasi, dan ini akan meningkatkan 
daya saing di setiap lomba. Kesalahan dalam pemilihan peserta didik dapat mengakibatkan kurangnya pendapatan prestasi, kehilangan kesempatan dalam bersaing, atau hal-hal serupa yang mengakibatkan rendahnya pencapaian prestasi.

Dalam menentukan peserta didik yang akan mengikuti lomba, sering kali pendidik salah perhitungan dalam memilih, dikarenakan tingkat mentalitas peserta didik tidak sama. Adanya perencanaan untuk memulai pelatihan dalam persiapan perlombaan diperlukannya pengambil keputusan yang tepat, untuk menentukan peserta didik yang kompeten di bidang perlombaannya. Selain karena faktor mentalitas dan ilmu pengetahuan yang kurang mumpuni, juga karena persaingan yang semakin meningkat.

Profile Matching adalah cara pengambilan keputusan dengan mengasumsikan bahwa terdapat tingkatan variable predictor yang ideal yang harus dipenuhi oleh subyek yang diteliti. Pengujian ini dilakukan untuk mengetahui performa peserta didik yang akan mengikuti perlombaan. Maka judul dari Penelitian ini adalah : "Penerapan Metode Profile Matching untuk menentukan peserta

\section{lomba pramuka"}

dengan maksud menerapkan metode profile matching dalam menentukan peserta didik yang siap untuk mengikuti kegiatan dan perlombaan yang bisa mendapatkan prestasi. Aadapun Proses Profile Matching adalah :
a. Menentukan Kriteria, subkriteria, dan nilai
b. Mencari nilai subkriteria objek
c. Menentukan gap
d. Menentukan core dan secondary factor
e. Menentukan nilai total
f. Menentukan rangking

\section{Rumusan Masalah}

Untuk mendapatkan sebuah prestasi dalam perlombaan bagi pelajar, diperlukan persiapan yang menyeluruh dari mulai menyiapkan kontingensi /tim yang sesuai /cocok dengan bidang perlombaannya, baik dari sisi pengetahuan, ketrampilan serta sikap mental peserta didik. Sekolah Dasar hingga Perguruan Tinggi tidaklah mudah, karena prestasi merupakan salah satu pengalaman dan point penting untuk menuju jenjang berikutnya. Salah satunya prestasi bisa didapatkan dengan cara berlomba pramuka dan mengikuti beberapa kegiatan yang diadakan khusus di JABODETABEK, JAWA BARAT, dan NASIONAL. Berikut data seluruh intansi pendidikan yang mengadakan lomba dan acara setiap tahunnya.

dilihat dari Tabel diatas, kegiatan perlombaan yang paling mendekati dengan waktu pelaksanaan adalah Kompetisi Pramuka yang diselenggarakan oleh MAN 2 Kota Bogor, dan jika dilihat dari 
Tabel dibawah jumlah peserta didik yang saat ini aktif hanya ada siswa. Sedangkan rata-rata siswa mengalami peningkatan pada saat tahun ajaran baru. Berikut data peserta didik yang aktif saat ini.

a. Identifikasi Masalah

Berdasarkan uraian diatas, maka dapat diidentifikasi masalah sebagai berikut :

1) Belum diketahui nilai peserta didik yang siap berlomba.

2) Belum adanya aplikasi untuk menampilkan hasil keputusan peserta didik yang siap untuk setiap perlombaan.

b. Rumusan Masalah

1) Problem Statement berdasarkan identifikasi masalah diatas maka dapat disimpulkan pokok masalah yaitu belum diketahui nilai peserta didik untuk berlomba

2) Research Questions Berdasarkan identifikasi masalah diatas maka dapat disimpulkan pokok masalah yaitu belum diketahui nilai peserta didik untuk berlomba?

\section{Maksud dan Tujuan Pengembangan}

a. Maksud

Menerapkan penerapan metode profile matching untuk menentukan peserta didik pramuka yang siap mengikuti perlombaan.

b. Tujuan

Mengetahui nilai kesiapan peserta didik pramuka untuk mengikuti kegiatan perlombaan

\section{Signifikansi Produk}

Pentingnya pengembangan dilakukan untuk memberikan solusi pengambilan keputusan berdasarkan data dan hasil dari penelitian pengembangan ini, yaitu 1) Keputusan, 2) Data, dan 3) Hasil

\section{Asumsi dan Keterbatasan Pengembangan}

Asumsi dari Penelitian ini yaitu sebagai berikut :

Data yang digunakan yaitu data peserta didik tahun 2017 yang berjumlah 56 siswa, dengan rincian kelas XI 30 siswa dan kelas XII 25 siswa dan kegiatan lomba yang dilakukan tahun 2017.

Keterbatasan Pengembangan Penelitian ini memiliki keterbatasan pengembangan yaitu sebagai berikut:

a. Penelitian terbatas hanya untuk menilai kesiapan peserta didik yang akan mengikuti kegiatan perlombaan yang didalam lomba tersebut hanya berkisar 6 orang yang terdiri dari mata lomba cerdas cermat.

b. Aplikasi yang dikembangkan berbasis web dengan bahasa pemograman visual basic dengan metode profile matching dan menggunakan database MySql.

\section{MODEL PENGEMBANGAN}




\section{Kerangka Pemikiran}

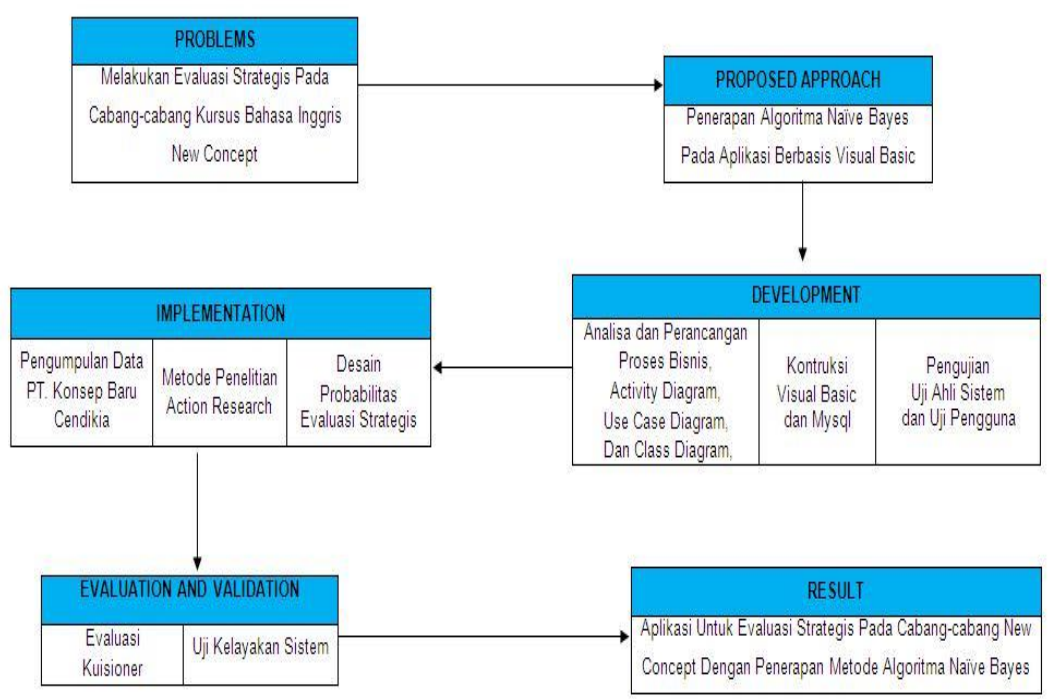

Gambar 1. Kerangka Pemikiran

Kerangka pemikiran merupak gambaran dari masalah yang akan diteliti, metode yang digunakan, cara pengambilan data, hasil penelitian hingga hasil pengembangan yang diterapkan pada aplikasi yang dibuat.

\section{Model Pengembangan}

Menurut Pressman (2012:50), dalam melakukan perancangan sistem yang akan dikembangkan dapat mengunakan metode prototype. Metode ini cocok digunakan untuk mengembangkan sebuah perangkat yang akan dikembangkan kembali.

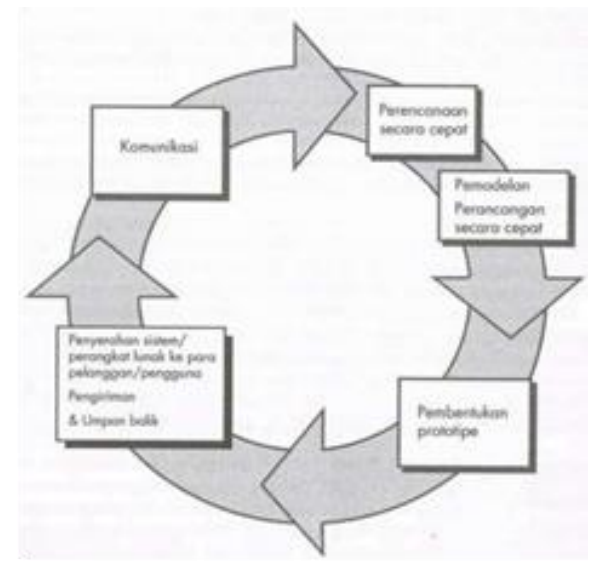

Gambar 2. Model Prototype

Gambar 2 merupakan gambaran model pengembangan yang dilakukan dalam penelitian dimana, model pengembangan yang dilakukan menggunakan metode pengembangan prototipe. Berikut tahapan-tahapan yang dilakukan dalam pengembangan model prototipe. 


\section{HASIL DAN PEMBAHASAN}

\section{Hasil}

Hasil penelitian akan diuaraikan berdasakan pada prosedur pengembangan adapun tahapan-tahapan yang dilakukan adalah :

\section{Analisa Kebutuhan}

Tahap ini dilakukan dengan cara pengumpulan kebutuhan yang dilanjutkan dengan analisis kebutuhan untuk memperoleh hasil analisis yang akan diterapkan dalam pengembangan aplikasi profile matching, analisi kebutuhan dilakukan dengan cara Pengumpulan Dokumen Pengumpulan dokumen dilakukan dalam rangka mengidentifikasi permasalahan dan kebutuhan data yang nantinya diperlukan dalam pengembangan. Identifikasi Kebutuhan Aplikasi Identifikasi kebutuhan aplikasi dilakukan dengan cara wawancara guna mengetahui variabel apa saja yang akan diterapkan pada aplikasi atau sistem ini, adapun pihak yang diwawancari adalah pihak admin dan pihak pelatih, beberapa hal tersebut meliputi : kebutuhan menu yang ada, notifikasi dan keluaran yang dihasilkan dari aplikasi ini.

\section{Quick Plan and Modelling Quick Plan}

Sebuah aplikasi akan berjalan dengan baik jika dilakukan perancangan yang baik pula. perancangan tersebut meliputi; use case diagram, activity diagram, dan class diagram.

a. Usecase Diagram

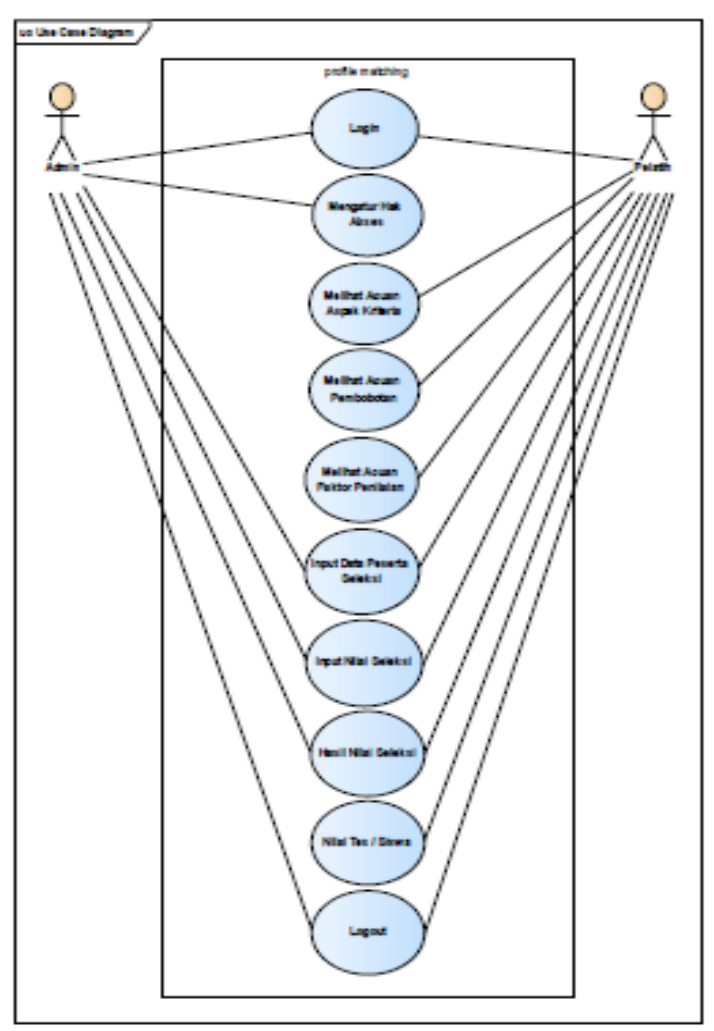

Gambar 3. Usecase Diagram 
b. Activity Diagram

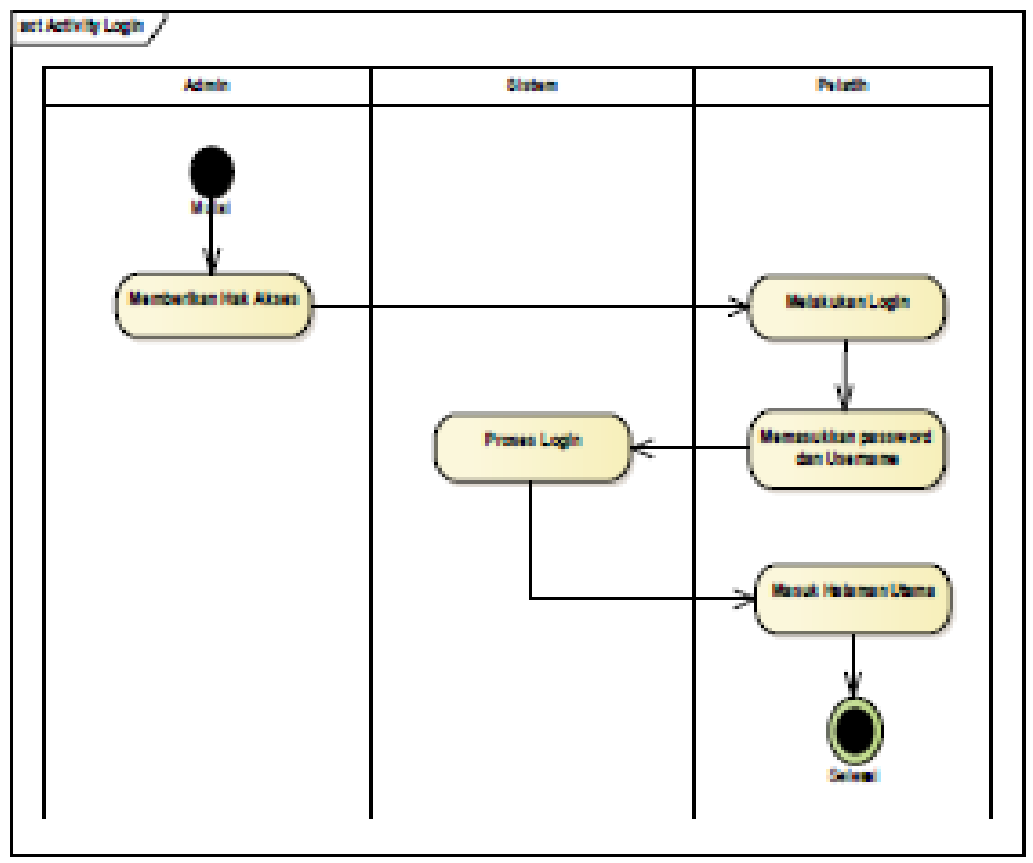

Gambar 4. Acktivity Diagram

c. Class Diagram

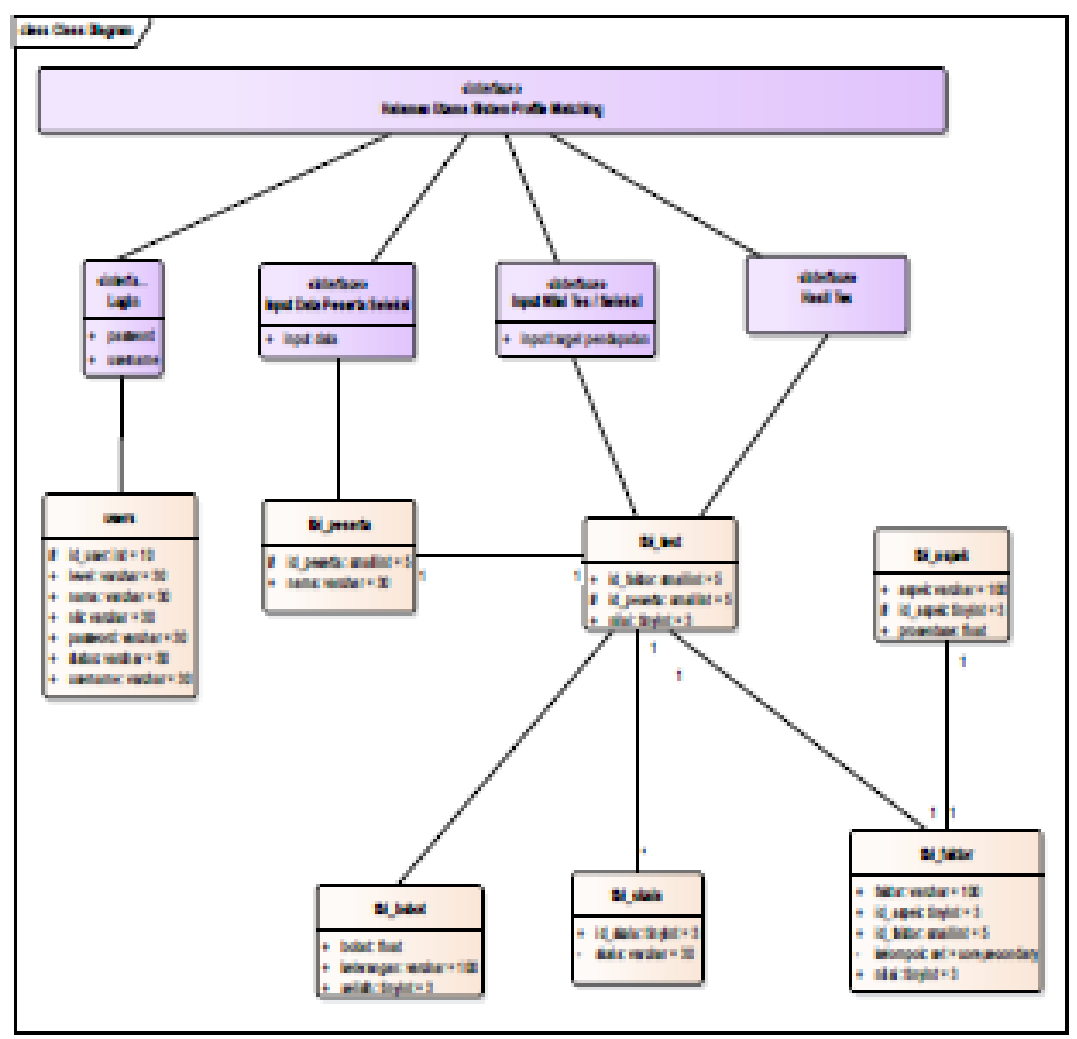

Gambar 5. Class Diagram 


\section{Implementasi Algoritma}

Hasil analisis data didapat dari penghitungan metode Profile Matching yang dimana hasil tersebut dapat dilihat pada gambar - gambar berikut :

$\begin{array}{cccc}\text { Kode Kriteria } & \text { Nama_Kriteria } & \text { Jenis_Kriteria } & \text { Presetase } \\ 1 & \text { Kecerdasan } & \text { Core Factor } & 30 \% \\ 2 & \text { Sikap } & \text { Core Factor } & 30 \% \\ 3 & \text { Perilaku } & \text { Secondary Factor } & 40 \%\end{array}$

\section{Gambar 6. Kriteria}

Berikut tabel penentuan faktor yang akan dijadikan penilaian seleksi.

$\begin{array}{cll}\text { Kode Kriteria } & \text { Kriteria } & \text { Faktor } \\ 1 & \text { Kecerdasan } & \text { Common Sense } \\ 2 & \text { Kecerdasan } & \text { Verbalisasi Ide } \\ 3 & \text { Kecerdasan } & \text { Sistematika berpikir } \\ 4 & \text { Kecerdasan } & \text { Penalaran dan Solusi Real } \\ 5 & \text { Kecerdasan } & \text { Konsentrasi } \\ 6 & \text { Kecerdasan } & \text { Logika Praktis } \\ 7 & \text { Kecerdasan } & \text { Fleksibilitas Berpikir } \\ 8 & \text { Kecerdasan } & \text { Imajinasi Kreatif } \\ 9 & \text { Kecerdasan } & \text { Antisipasi } \\ 10 & \text { Kecerdasan } & \text { Potensi Kecerdasan } \\ 11 & \text { Sikap Kerja } & \text { Energi Psikis } \\ 12 & \text { Sikap Kerja } & \text { Ketelitian dan Tanggung jawab } \\ 13 & \text { Sikap Kerja } & \text { Kehati-hatian } \\ 14 & \text { Sikap Kerja } & \text { Pengendalian Perasaan } \\ 15 & \text { Sikap Kerja } & \text { Dorongan berprestasi } \\ 16 & \text { Sikap Kerja } & \text { Vitalitas Perencanaan } \\ 17 & \text { Perilaku } & \text { Kekuasaan (Dominance) } \\ 18 & \text { Perilaku } & \text { Pengaruh (Influence) } \\ 19 & \text { Perilaku } & \text { Keteguhan Hati (Steadiness) } \\ 20 & \text { Perilaku } & \text { Pemenuhan (Compliance) } \\ & & \end{array}$

Gambar 7. Faktor Seleksi

Setelah Tabel penentuan di ketahui, dibuatlah tahap penilaian sebagai berikut : 


\begin{tabular}{|c|c|c|c|c|}
\hline \multicolumn{5}{|c|}{ Nilai Profil Peserta } \\
\hline $\operatorname{coda} \mathrm{Ni}_{\mathrm{i}}$ & Peserts & Krteria & faltor & Kilai Profil \\
\hline 1 & Adan & Kecerdasan & Common Sense & 2 \\
\hline 2 & Adlan & Kecerdasen & Verbalisasi Ide & 4 \\
\hline 3 & Adan & Kecerdasan & Sistematika berpikir & 3 \\
\hline 4 & Adan & Kecerdasen & Penalaran den Solusi Real & 3 \\
\hline 5 & Adian & Kecordasen & Konsentrasi & 2 \\
\hline 6 & Adian & Kecerdassan & Logila Praitis & 2 \\
\hline 7 & Adan & Kecendasen & Fleksibitas Berpilir & 4 \\
\hline 8 & Adlan & Kecardassan & Imajnasi Kreatif & 3 \\
\hline 9 & Adan & Kecerdasen & Antsipasi & 2 \\
\hline 10 & Adan & Kecerdassan & Potensi Kecerdasen & 3 \\
\hline 11 & Adlan & Slap Keja & Energi Psiks & 3 \\
\hline 12 & Adan & Skap Keja & Ketelitian dan Tangzung jawab & 4 \\
\hline 13 & Adan & Slikap Kerja & Kehat hation & 3 \\
\hline 14 & Adan & Sicap Kkrja & Pengendalian Perasaan & 1 \\
\hline 15 & Adlan & Slap Kerja & Dorecragen berprestasi & 3 \\
\hline 16 & Adan & Sklap Kerja & Vitaltas Perencanesn & 1 \\
\hline 17 & Adan & Perilaku & Kekussanan (Dominance) & 4 \\
\hline 18 & Adlan & Perilaku & Pengaruh (Influence) & 4 \\
\hline 19 & Adolan & Perilaku & Keteguhan Hat (Steadiness) & 4 \\
\hline 20 & Adlan & Perlaku & Pemenuhan (Compliance) & 4 \\
\hline
\end{tabular}

Gambar 8. Penilaian

Setelah tahap penilaian selesai maka penerapan profile matching dilakukan seperti gambar berikut:

\begin{tabular}{|c|c|c|c|c|c|c|}
\hline \multicolumn{7}{|c|}{ PENERAPAN PERHITUNGAN PROFILE MATCHING } \\
\hline Nilai Profile & Nilai Profil Standar & Gap & Nilai Gap & Jenis Kriteria & Rata2 & Total Nilai \\
\hline 2 & 3 & -1 & 4 & \multirow{16}{*}{ Core $(60 \%)$} & \multirow{16}{*}{3,93} & \multirow{20}{*}{4,16} \\
\hline 4 & 3 & 1 & 4,5 & & & \\
\hline 3 & 4 & -1 & 4 & & & \\
\hline 3 & 4 & -1 & 4 & & & \\
\hline 2 & 3 & -1 & 4 & & & \\
\hline 2 & 4 & -2 & 3 & & & \\
\hline 4 & 4 & 0 & 5 & & & \\
\hline 3 & 5 & -2 & 3 & & & \\
\hline 2 & 3 & -1 & 4 & & & \\
\hline 3 & 4 & -1 & 4 & & & \\
\hline 3 & 3 & 0 & 5 & & & \\
\hline 4 & 4 & 0 & 5 & & & \\
\hline 3 & 2 & 1 & 4,5 & & & \\
\hline 1 & 3 & -2 & 3 & & & \\
\hline 3 & 3 & 0 & 5 & & & \\
\hline 1 & 5 & -4 & 1 & & & \\
\hline 4 & 3 & 1 & 4,5 & \multirow{4}{*}{ Secondary ( $40 \%)$} & \multirow{4}{*}{4,5} & \\
\hline 4 & 3 & 1 & 4,5 & & & \\
\hline 4 & 4 & 0 & 5 & & & \\
\hline 4 & 5 & -1 & 4 & & & \\
\hline
\end{tabular}

Gambar 9. Penerapan Profile Matching

\section{Pembahasan}

\section{Deployment Delivery and Feedback}


Perhitungan persentase kualitas sistem secara keseluruhan dari data yang sudah didapatkan sebagai berikut :

$$
\begin{aligned}
P & =\frac{f 1+f 2+f 3}{\sum N} \times 100 \% \\
& =\frac{39+50+46}{50+50+50} \times 100 \% \\
& =\frac{135}{150} \times 100 \% \\
& =90 \%
\end{aligned}
$$

Persentase yang didapat sebesar 90\%, maka dapat dikategorikan Sangat Layak. Saran dan masukan oleh penguji menjadi bahan pertimbangan dalam pengembangan sistem profile matching untuk ektrakulikuler pramuka

\section{SIMPULAN DAN SARAN}

Berdasarkan dari hasil penelitian dan implementasi sistem maka dapat disimpulkan sebagai Berikut :

1. Peserta didik dari sebanyak 56 siswa yang lolos sebagai peserta lomba cerdas cermat ada 6 siswa yang terbagi dari 2 tim dengan nama dan nilai tim $1: 1$. Rizki Bahtiar (4.373), 2. Riyan (4.315), 3. M. Adlan Ridhani (4.278), dan tim 2 : 1. Nurzaman (4.227). 2. Vinna Novita Sari (3.806), dan 3. Noval F (3.774). sedangkan yang tidak lolos seleksi sebanyak 50 siswa yang akan diseleksi kembali untuk mata lomba lain.

2. Hasil keputusan dari sistem profile matching menyatakan bahwa jika peserta didik sesuai dengan ranking yang sudah di tetapkan maka peserta didik siap untuk menjalani lomba, tetapi jika peserta didik tidak masuk pada ranking yang telah ditentukan maka peserta didik masih belum dapat untuk mengikuti perlombaan. Hasil unjuk kerja sistem profile matching masuk dalam kategori "Layak". Nilai persentase hasil pengujian pada sistem untuk setiap faktor, yaitu: functionality sebesar 69\%(Layak), efficiency sebesar 70\%(Layak), dan usability sebesar 65\%(Layak). Persentase total dari kualitas sistem adalah 90\% (Sangat Layak).

\section{DAFTAR RUJUKAN}

Turban. "Sistem Pendukung Keputusan (Decision Support System)." (2005)

Kusrini. "Profile Matching atau Pencocokan Profile." (2007)

Pressman. "Software Quality International Organization of Standardization (ISO) 26.” (2010:488)

Masitoh, \& Akip Suhendar "Penerapan Metode Profile Matching Dalam Pengembangan Aplikasi ECommerce Pada Penjualan Barang Elektronik" (2016).

Sugiono . Metode Penelitian Kuantitatif dan R\&D. Bandung Alfabeta 2013

Suharmi Arikunto. Prosedur Penelitian Suatu Pendekatan Praktik. Jakarta Rineka Cipta.2010 